Denysiuk 5.,
Kotsar 0.,
Opryshko V.

\title{
INCREASING THE ENERGY EFFICIENCY OF WAREHOUSES USING DEMAND-SIDE MANAGEMENT MECHANISMS
}

Досліджено проблему підвищення рівня енергоефективності складських приміщень в ланцюзі транспортно-логістичної системи. Встановлено доцільність застосування програм з управління попитом на енергетичні ресурси з подальшим аналізом параметрів та якості електроенергї як одного з ключових факторів підвищення енергоефективності. Представлено результати застосування показника неактивної потужності Фризе при оцінці нерівномірності споживання електричної енергіi.

Ключові слова: управління попитом на енергетичні ресурси, енергоефективність будівель, транспортно-логістична інфраструктура.

\section{Introduction}

The problem of realization of Ukraine's transit potential in the system of international transport and communication links goes beyond the borders of Ukraine's own interests in connection with its gravitation towards the geographical center of Europe [1,2]. Such territorial feature of Ukraine can determine the priorities of the country's development in the direction of closer integration with the countries of the European Union and other international institutions [3].

The development of logistics operations significantly affects the development of the economic situation of individual regions and countries of Europe. Ukraine, having a high transit rating in Europe, requires a phased implementation of institutional changes in the transport sector of the economy. An important problem is the location of elements of the transport and logistics infrastructure as energy and resource saving facilities in the maintenance of freight traffic $[4,5]$.

Warehouses are one of the most important elements of logistics systems [6-9]. At all stages of the movement of material products, from the primary source of raw materials to the final consumer, there is an objective need for specially equipped places for keeping stocks. This explains the presence of a large number of different types of warehouses. The movement of material production through the warehouse increases the value of the goods, which is associated with the corresponding costs. Therefore, it is necessary to study the problems and methods of effective organization and operation of warehouses to rationalize traffic in the logistics chain and reduce costs.

Investments in energy efficiency in such important service sector as logistics can lead to significant energy savings (for example, Directive 2012/27/EU, the existing energy saving potential of buildings is $40 \%$ ) [10]. Reducing the energy costs of logistics companies increases efficiency and expands opportunities for international trade (export/import transactions), while eliminating international tariff barriers and the impact of a number of other negative factors.

\section{The object of research and its technological audit}

The object of research is the processes of increasing energy efficiency in warehouses. Effective logistics schemes are often not implemented due to a combination of factors and barriers. These include, for example, high unit costs for such operations as warehousing, sorting, transportation, etc. These factors are faced by the subjects involved in logistics operations, such as employees, decision-makers, auditors, financial institutions and others.

Warehouses can differ both in size, design features, levels of mechanization of warehouse operations, and by functional purpose and mode of storage.

Warehouse can be a link in the movement chain of production products (warehouses of raw materials, finished products, specialized warehouses, etc.), or be on the site of movement of consumer goods (commodity warehouses). Warehouse is not just a place where different goods are located $[11,12]$. It has a certain internal structure, which is quite developed. Warehouse consists of several zones, differing in purpose and equipment, which is used. The following main zones are distinguished: loading and unloading, receiving, storage, sorting, expeditions, administrative and household facilities. For storage and transportation of goods a variety of equipment is used (manual devices are used, heavy and dimensional items are moved by cranes and loaders).

Increasing energy efficiency in services, including logistics operations, in accordance with EU Directive 2012/27/EU, 2012/27/EU, provides for mandatory energy audits as the basis for increasing energy efficiency. This process corresponds to the implementation of the European policy of modernization of transport corridors, creating broad opportunities for attracting investors.

Reduction of the energy consumption in the organization of traffic flow is possible with a logistics approach to supply chain management [13]. The issues of rational use and allocation of resources are one of the main ones in logistics. The strategic goal of logistics supply chain management is resource saving, minimizing costs for materials, fuel and energy. A modern solution to increase the 
energy efficiency of the transport and logistics complex in the organization of cargo transportation is the maintenance of the freight flow in the system of producer-logistics center-consumer.

One of the key issues in the formation of an energy efficient transport and logistics infrastructure is the choice of the optimal location of the logistics center in terms of logistics costs, profit and energy efficiency in the process of servicing the cargo flow. The optimal location of the logistics center will contribute to energy and resource saving in the transport sector by reducing empty runs, fuel costs, increasing the utilization of the carrying capacity and cargo capacity of the vehicle. A successful location will create conditions for the use of energy-efficient types of vehicles, thereby reducing the energy intensity of transport.

Most of the existing approaches to optimizing the location of logistics facilities allow to determine the optimal location for the elements of the transport and logistics infrastructure, taking into account only transportation costs. There is no assessment of energy efficiency as a whole in such approaches, and only factors such as the volume of traffic, distance, and cost of transportation are considered [14, 15]. To the shortcomings of the existing methods of location of logistics objects can be attributed also:

- static data - does not take into account possible changes in the factors of sources of consumption and supply;

- the limitations of considered factors - market, socioeconomic and infrastructural factors are not considered [16-18]. Consumers, like owners of warehouses, tend to reduce their own costs, there is a problem of management in terms of costs for consuming energy resources and finding the optimal mode of operation. It is advisable to develop a methodology, to take into account in a complex the various market factors affecting the efficiency of the transport and logistics infrastructure, the dynamics of changes in energy efficiency indicators and the possibility of energy and resource saving. Such methodology should include processes for introduction and application of energy demand-side management systems, including monitoring of non-optimal consumption.

\section{The aim and objectives of research}

The aim of research is to determine the features of the processes of analyzing the energy efficiency of warehouses in the current market conditions and expanding the analysis by creating a tool for assessing the consumption optimality.

To achieve this aim, it is necessary to solve the following tasks:

1. To conduct a comprehensive analysis of energy efficiency factors of warehouses as an element of the transport and logistics system in accordance with the applicable norms and standards in the field of energy efficiency of buildings in the European Union.

2. To assess the unevenness of the power consumption graphs of warehouses.

3. To investigate the changes in the Frieze inactive power index as a factor of non-optimality and a mean of reducing costs.

\section{Research of existing solutions of the problem}

It is important to take into account such factors of energy efficiency of transport and logistics infrastructure as:

1) socio-economic factors (population size, average incomes, gross regional product, industrial output, retail turnover, import and export turnover, pollution level);

2) infrastructure and geographical factors (density of highways and railways, availability of transport corridors on the territory of the region, climatic zone);

3 ) indicators of transport activities in the region (freight traffic by road and rail, the volume of transport services per capita).

There are two main classifications of warehouses: Knight Frank and Swiss Realty Group [10, 19, 20]. Knight Frank classifies warehouses from the best $\mathrm{A}+$ to a satisfactory $\mathrm{D}$, in turn Swiss Realty Group classifies from A1 to unsatisfactory D.

In general, in order to obtain the maximum level for any of the existing classifications, the following set of compliance criteria is formed:

1. Modern single-store warehouse building made of light metal structures and sandwich panels, mostly rectangular without columns or with a column pitch at least 12 meters, and with distance between bays not less than $24 \mathrm{~m}$.

2. High ceilings not less than $13 \mathrm{~m}$, allowing installation of multi-level racking equipment (6-7 tiers).

3. Smooth concrete floor with anti-dust coating, with a load at least $5 \mathrm{t} / \mathrm{m}^{2}$, at a level of $1.20 \mathrm{~m}$ from the ground.

4. High design load on the floor surface (from $4 \mathrm{t} / 1 \mathrm{~m}^{2}$ ), which makes it possible to use heavy vehicles (high rack stackers) and, as a consequence, maximize the height of the shelves.

5. Availability of a fire alarm system and an automatic fire extinguishing system.

6. Availability of a ventilation system.

7. Security alarm system and video surveillance system.

8. Autonomous electrical power substation and heat unit.

9. Availability of a sufficient number of automatic dock shelters with dock levelers (at least 1 per $500 \mathrm{~m}^{2}$ ).

10. Availability of sites for parking of heavy vehicles and cars.

11. Availability of sites for maneuvering of heavy vehicles.

12. Availability of office premises at a warehouse.

13. Availability of auxiliary premises at the warehouse (toilets, showers, utility rooms, locker rooms for staff).

14. Availability of accounting and control system of staff access.

15. Fiber-optic telecommunications.

16. Fenced and around the clock guarded illuminated landscaped territory.

17. Location near the central highways.

18. Professional management system.

19. Experienced developer.

20. Railway branch.

Energy efficiency indicators are an important component in the formation of an energy efficient transport and logistics infrastructure. However, they can't predict changes in overall energy consumption or quantify the impact of individual components or factors on overall energy consumption. Therefore, it is often necessary to carry out a more detailed analysis to understand the combined ef- 
fect of a number of different factors or driving forces on overall energy consumption [21].

It is worth paying attention to the advisability of applying the «Economic evaluation procedure for energy systems in buildings», presented in the standard EN 15459:2007 [22]. In the presence of automation and building management mechanisms in accordance with EN 15232:2007 [23], the efficiency of the use of trigeneration [24] for different zones of warehouses is obvious. This leads to the emergence of the issue of demand-side management for electricity.

Demand-side management (DSM) is a set of methods and strategies that work to align the daily energy consumption schedule. DSM allows to monitor the consumers in the context of effective system management [25]. When creating an energy efficient transport and logistics infrastructure, DSM programs can be represented not only by algorithms of normative and legal actions when regulating load levels. One of the ways of using them is direct control of loads at the level of technological processes [26]. This determines the need for precise regulation of energy processes in the network, taking into account the requirements for electricity quality, reliability and stability of electricity supply [27]. As a result, there is a need to assess the efficiency of the system and take into account the relevant factors affecting the quality of electrical energy, namely: signal distortion, current ripple to voltage, etc. To obtain the desired level of efficiency of transmission and consumption of electrical energy and to reduce losses, it is necessary to identify factors that are directly influenced and the processes by which these factors can be identified.

\section{Methods of research}

The analysis shows that modern DSMs are based on an integral approach to their implementation and cover organizational and technical measures for solving the set tasks, including using distributed generation (DG). The main tool for optimizing the instantaneous power consumption graphs $P$ after a certain time interval $t$ due to DSM programs is presented in Table 1. In analyzing the optimization process, the unevenness due to the influence of various factors that depend not only on the consumer and the generator but also on the power supply system as a whole should be taken into account.

Table 1

The main tool for optimizing the consumption graphs

\begin{tabular}{|c|c|c|c|}
\hline $\begin{array}{c}\text { № of } \\
\text { program }\end{array}$ & $\begin{array}{c}\text { General view of electric power consump- } \\
\text { tion graph } P(t) \text { and the direction of } \\
\text { optimization }\end{array}$ & $\begin{array}{l}\text { Name of DSM } \\
\text { program }\end{array}$ & $\begin{array}{l}\text { Description of programs and their } \\
\text { general characteristics }\end{array}$ \\
\hline 1 & ${ }^{\mathrm{P}} \uparrow$ & $\begin{array}{l}\text { Reduction of peak } \\
\text { load }\end{array}$ & $\begin{array}{l}\text { The programs are aimed at equali- } \\
\text { zing the consumption graph through } \\
\text { direct load control, disabling of } \\
\text { consumer equipment or DG intro- } \\
\text { duction }\end{array}$ \\
\hline 2 & ${ }^{\mathrm{P}} \uparrow$ & Filling of failures & $\begin{array}{l}\text { Programs that encourage the off- } \\
\text { peak consumption. They are aimed } \\
\text { at increasing their own consump- } \\
\text { tion in the areas of the general } \\
\text { decline in energy consumption. } \\
\text { Stimulation of consumers is usually } \\
\text { carried out at much lower tariffs }\end{array}$ \\
\hline 3 & ${ }^{\mathrm{P}} \uparrow$ & $\begin{array}{l}\text { Energy saving } \\
\text { strategies }\end{array}$ & $\begin{array}{l}\text { Programs for seasonal reduction of } \\
\text { energy consumption, mainly due to } \\
\text { efficient energy consumption and } \\
\text { loss reduction }\end{array}$ \\
\hline 4 & $\mathrm{P} \uparrow$ & Load building & $\begin{array}{l}\text { Programs to manage the seasonal } \\
\text { increase in energy consumption. } \\
\text { They are based on the introduction } \\
\text { of intelligent systems and proces- } \\
\text { ses, more efficient equipment and } \\
\text { modern energy sources to achieve } \\
\text { a greater level of energy efficiency }\end{array}$ \\
\hline 5 & $\mathrm{P} \uparrow$ & Load transfer & $\begin{array}{l}\text { Programs to transfer the load from } \\
\text { the period of the greatest consump- } \\
\text { tion in the period of low consump- } \\
\text { tion, without changing the total } \\
\text { consumption. This is also possible } \\
\text { with DG inclusion }\end{array}$ \\
\hline 6 & $\mathrm{P} \uparrow$ & Flexible modeling & $\begin{array}{l}\text { A set of actions and integrated plan- } \\
\text { ning between generating companies } \\
\text { and consumers, taking into account } \\
\text { the needs at a given time. This } \\
\text { partnership is aimed at creating } \\
\text { a limitation model of capacity and } \\
\text { energy consumption that an indi- } \\
\text { vidual consumer can use at a spe- } \\
\text { cific time, through the installation } \\
\text { of load-limiting devices }\end{array}$ \\
\hline
\end{tabular}


Analysis of the features of warehouse facilities and warehouse operations allows to form their model from the point of view of solving the following problems:

1) optimization of energy consumption modes (first of all, power consumption);

2) adequate assessment of energy (electricity) costs for storage and processing of a particular batch of goods;

3) minimization of storage costs for storage and processing of goods.

The composition model as an element of the load of the power supply network is characterized by the following features:

- load level changes (can be set) in a deterministic way;

- presence of smoothly and sharply variable loads;

- accounting for the variable function of the cost of electricity prices during the day;

- impact of individual operations (technological) on the value component can be clearly delineated with the allocation of influence factors.

To expand the possibilities for managing demand for electricity, it is necessary to create a tool for monitoring and assessing the optimality of energy consumption and quality.

\section{Research results}

The model of such consumption can be represented by an $R L$-load with variables in time $R(t)$ and $L(t)$. For a detailed analysis of the effect, let's perform a piecewise linear approximation. On the time interval of $T_{\text {calc }}$ it is possible to select an interval $T_{R, i} \in\left[0, T_{\text {calc }}\right]$ та $T_{L, j} \in\left[0, T_{\text {calc }}\right]$, and when it is possible to write $R i=$ const, $i=1, n_{R} ; L_{i}=$ const, $j=1, n_{L}$ for the $R L$-model; $L_{i}=$ const, $j=1, n_{L}$. Comparing the intervals $T_{R, i}, T_{L, j}$ - one can obtain a set of intervals $T_{C, K}$, when $L_{K}=$ const, $R_{K}=$ const, $K=1, n_{C}, \sum_{K=1}^{n} T_{C, K}=T_{\text {calc }}$, for the $k$-th interval:

$$
Z_{K}=\sqrt{R_{K}^{2}+\omega_{1}^{2} L_{K}^{2}} .
$$

Since for the duration of the transient processes $t_{K, t r a n s}$, the change in the $R_{K}$ and $L K$ parameters takes place $t_{K, \text { trans }} t_{K}$, then their influence can be neglected for further modeling of the transient processes.

Managing its own consumption of electrical energy, there is a need to assess its quality. The quality assessment of electricity must be based on physically understandable and obvious values, it is obvious that reactive power and reactive energy are not such in distorting systems. One of the values suitable for assessing the nature of electricity consumption, there are power losses that arise in the network when it is transmitted to the consumer.

The ratio of the smallest possible voltage loss value proportional to the square of the current values is proposed as this measure [28]. The current power factor value is expressed as:

$$
\lambda=\sqrt{\frac{\Delta P_{\min }}{\Delta P}}=\sqrt{\frac{3 I^{\prime 2}}{\Sigma I^{2}}} .
$$

Assuming that the system of voltages is symmetrical, balanced and sinusoidal, we can write the averaged over the time interval power factor $\lambda_{T}$ in the form:

$$
\lambda_{T}=\frac{A_{P}}{\sqrt{\left(U^{2}\right)}} \frac{1}{\sqrt{A\left(I^{2}\right)}} .
$$

The expression for $\lambda_{T}$ is valid for any network voltage. Therefore, $\lambda_{T}$ is an indicator, depends only on the consumer and takes into account the adverse effect of uneven consumption.

When assessing the current level of power consumption, the expression for Frieze inactive power $Q_{F}^{2}=S^{2}-P^{2}$ is actually the quadratic degree of the discrepancy between the total $S$ and the active power P. Even in the absence of reactive elements, the $Q_{F}>0$ ratio occurs in the control interval $T_{T}$ when the processes flow unevenly.

The general form of inactive power:

$$
Q_{F}=\sqrt{U^{2} I^{2}-P^{2}} .
$$

The application of $Q_{F}$ to assess the unevenness of processes is shown by the example of a mode, characterized by the acting values of the voltage $U_{i}$ and the current $I_{i}$, $i=1, \ldots, n, T_{i}$ is the duration of the $i$-th interval, and $P=U_{0} I_{0}$, where $U_{0}, I_{0}$ are the averaged values of voltage and current. Under the condition $\cos \varphi=1$ for the interval $T_{m}>T_{T}$, where $T T$ is the electric network period, let's write the expression for the Frieze power $Q_{F}$ in the form:

$$
Q_{F}=\sqrt{\left(\sum_{i=1}^{n} U_{i}^{2} \frac{T_{i}}{T}\right)\left(\sum_{j=1}^{n} I_{j}^{2} \frac{T_{i}}{T}\right)-U_{0}^{2} I_{0}^{2}} .
$$

If we introduce the notation $\delta_{i}=T_{i} / T ; \sum_{i=1}^{n} \delta_{i}=1$, then $Q_{F}$ is determined from the relation:

$$
Q_{F}=\sqrt{\sum_{i=1}^{n} U_{i}^{2} \delta_{i} \cdot \sum_{i=1}^{n} I_{i}^{2} \delta_{i}-\sum_{i=1}^{n}\left(U_{i} I_{i} \delta_{i}\right)^{2}} .
$$

$Q_{F} / P$ value characterizes the efficiency of regulation of the power consumption mode and determines the level of non-optimal transmission of energy in terms of eliminating its losses.

$Q_{F}$ value plays an important role in the processes:

- calculation of losses;

- mutual settlements with consumers;

- generation control;

- regulation of network modes;

- control of accumulators of electric energy.

When assessing the current level of power consumption, the expression for the Frieze inactive power $Q_{F}^{2}$ is in fact a quadratic degree of the discrepancy between the total $S$ and the active power $P$. Even in the absence of reactive elements, the ratio $Q_{F}>0$ for the non-uniformity of the processes takes place in the control interval $t_{m}$. The application of $Q_{F}$ to assess the unevenness of processes is shown by the example of the regime, characterized by the acting values of the voltage $U_{i}$ and the current $I_{i}, i=1, \ldots, n, T_{i}$ is the duration of the $i$-th interval, and $P=U_{0} I_{0}$, where $U_{0}, I_{0}$ are the corresponding values of voltage and current.

To distribute the characteristic over the entire process interval, it is necessary to write out and substitute the 
value for voltage and current for two intervals. Accordingly, let's introduce the notation $\delta_{i}=t_{i} / \sum t_{i}, k_{i, j}=I_{j} / I_{1}$ for the process on a large interval $T=\sum t_{i}, \quad k_{u, j}=U_{j} / U_{1}$, and obtain:

$$
\begin{aligned}
& U_{0}=\frac{U_{1} t_{u}+U_{2}\left(T-t_{u}\right)}{T}=U_{1} \delta_{u}+U_{1}\left(1-\delta_{u}\right), \\
& I_{0}=\frac{I_{1} t_{i}+I_{2}\left(T-t_{i}\right)}{T}=I_{1} \delta_{i}+I_{2}\left(1-\delta_{i}\right) .
\end{aligned}
$$

Substituting the obtained equations into the general formula, obtain the relation:

$$
\begin{aligned}
& P=U_{0} I_{0}=\left(U_{1} \delta_{u}+U_{2}\left(1-\delta_{u}\right)\right)\left(I_{1} \delta_{i}+I_{2}\left(1-\delta_{i}\right)\right), \\
& U=\sqrt{\frac{1}{T}\left(U_{1}^{2} t_{u}+U_{2}^{2}\left(T-t_{u}\right)\right)}=\sqrt{U_{1}^{2} \delta_{u}+U_{2}^{2}\left(1-\delta_{u}\right)} .
\end{aligned}
$$

Let's suppose that the values of the voltage $U_{1}$ and the current $I_{1}$ in the first interval differ from the values of the voltage $U_{2}$ and the current $I_{2}$ in the second interval by some deviation coefficients $k_{u}, k_{i}$. Accordingly, the voltage and current values in the second interval take the form $U_{2}=k U U_{1}$ and $I_{2}=k_{i} I_{1}$.

Formulas for active power $P$ and power $Q_{F}$ can be represented as:

$$
\begin{aligned}
& P=\sum_{i=1}^{n} U_{i} I_{i} \delta_{i}, \\
& P=U_{1} I_{i}\left(\delta_{i}+\sum_{j=2}^{n} k_{i, j} k_{u, j}\right), \\
& Q_{F}^{2}=\left[U_{1}^{2} \delta_{u}+U_{2}^{2}\left(1-\delta_{u}\right)\right] \cdot\left[I I_{1}^{2} \delta_{i}+I I_{2}^{2}\left(1-\delta_{i}\right)\right]- \\
& \left(\left[U_{1} \delta_{u}+U_{2}\left(1-\delta_{u}\right)\right] \cdot\left[I I_{1} \delta_{i}+I I_{2}\left(1-\delta_{i}\right)\right]\right)^{2}, \\
& Q_{F}^{2}=U_{1}^{2} I\left(\delta_{u}+k_{u}^{2}\left(1-\delta_{i}\right)\right) \cdot\left(\delta_{i}+k_{i}^{2}\left(1-\delta_{i}\right)\right)- \\
& -\left(\left(\delta_{u}+k_{u}\left(1-\delta_{u}\right)\right) \cdot\left(\delta_{i}+k_{i}\left(1-\delta_{i}\right)\right)\right) .
\end{aligned}
$$
level:

Taking the current and voltage values $U_{1}, I_{1}$ as base

$$
\begin{gathered}
Q_{F}^{2}=-U_{1}^{2} I I_{1}^{2}\left[\begin{array}{l}
\left(\delta_{1}+\sum_{j=2}^{n} \delta_{j} k_{i, j} k_{u, j}\right)+ \\
+\left(\delta_{1}+\sum_{j=2}^{n} \delta_{j} k_{i, j}^{2}\right) \cdot\left(\delta_{1}+\sum_{j=2}^{n} \delta_{j} k_{u, j}^{2}\right)
\end{array}\right], \\
S^{2}=U_{1}^{2}\left(\delta_{1}+\sum_{j=2}^{n} \delta_{j} k_{i, j}\right) I_{1}^{2}\left(\delta_{1}+\sum_{j=2}^{n} \delta_{j} k_{u, j}\right) .
\end{gathered}
$$

With a proportional increase in voltage and current $k U_{1}=k i_{1}=1$ for the interval $t_{m}>t_{g}$, where $t_{m}$ is the electric network period, $t_{g}$ is the generation period, let's write the expression for the Frieze power $Q_{F}$ in the form:

$$
\begin{aligned}
& S^{2}=\left(\sum_{i=1}^{n} U_{1}^{2} \delta_{i}\right) \cdot\left(\sum_{i=1}^{n} I_{j}^{2} \delta_{j}\right), \\
& Q_{F}^{2}=U_{1}^{2}\left[\left(\sum_{j=1}^{n} \delta_{j} k_{i, j}^{2}\right) \cdot\left(\sum_{j=1}^{n} \delta_{j} k_{u, j}^{2}\right)-\left(\sum_{j=1}^{n} \delta_{j} k_{i, j} k_{u, j}\right)\right] .
\end{aligned}
$$

Assuming that the quantities in Eq. (10) in a certain mode take the corresponding values:

$$
\begin{aligned}
& U_{1}=1000 B, I_{1}=100 A, \\
& \delta_{i}, \delta_{u} \in\{0.2 ; 0.8\}, \quad k_{u}, k \in\{0.8 ; 1.2\},
\end{aligned}
$$

let's obtain a graph, indicates the presence of a dependence of $Q_{F}$ value and nature of the change in the value for fixed values $\delta_{u}=\delta_{i}$ (Fig. 1).

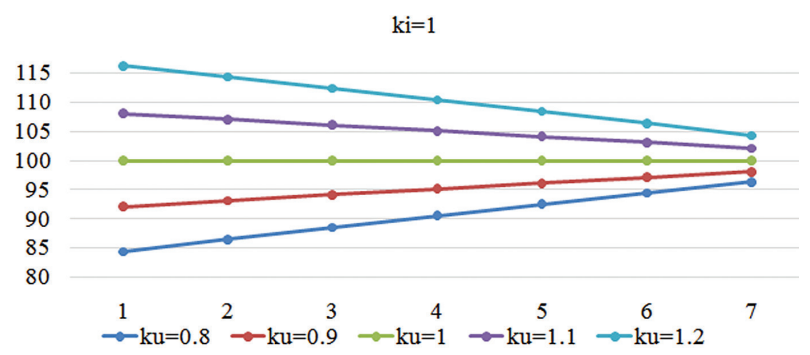

Fig. 1. Change in the $Q_{F}$ indicator for $k u=1$

3 cases are typical for the consumption mode, when the current and voltage deviation can't exceed the established level of $10 \%$ :

1. Having fixed the value of current deviation coefficient $k i$ and at level $k i=1.1$, the graph (Fig. 2) illustrates the consumption pattern in which the consumed current is higher than the base level, and the voltage fluctuates within the permissible range. The change in the Frieze power index comes with an increase in the time coefficient $\delta$, however, when the voltage drop approaches the permissible value $k u=0.9$, the shape of the graph changes and $Q_{F}$ indicator begins to increase (Fig. 2).

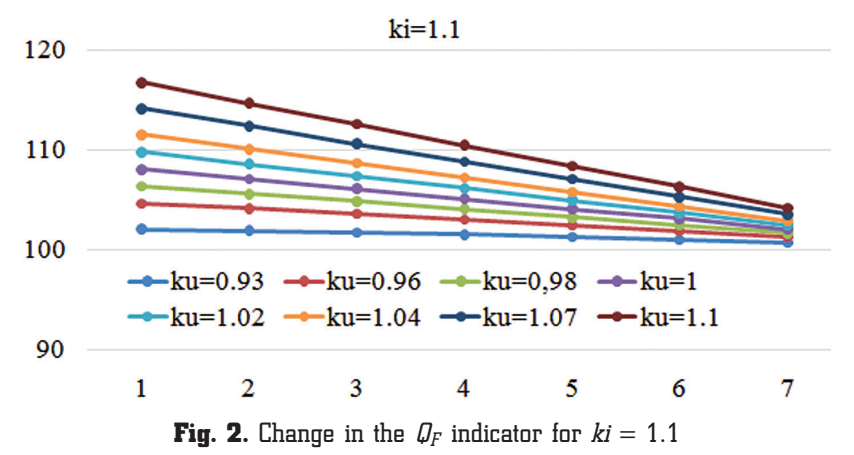

2. Similarly, fixing the value of the current deviation $k i$ and at the level $k i=0.9$, let's obtain a group of graphs, where $Q_{F}$ indicator increases, and also the approximation to the admissible value $k u=1.1$, when the indicator begins to decrease (Fig. 3).

3. At $k i=k u$, the change in the $Q_{F}$ value occurs with the smallest variations, which generally characterizes the deviation degree from the optimal consumption regime and the failure to comply with the basic (uniform) consumption 
regime. The uniformity is affected both by changes in the duration indicator and by the amplitudes of the effective values.

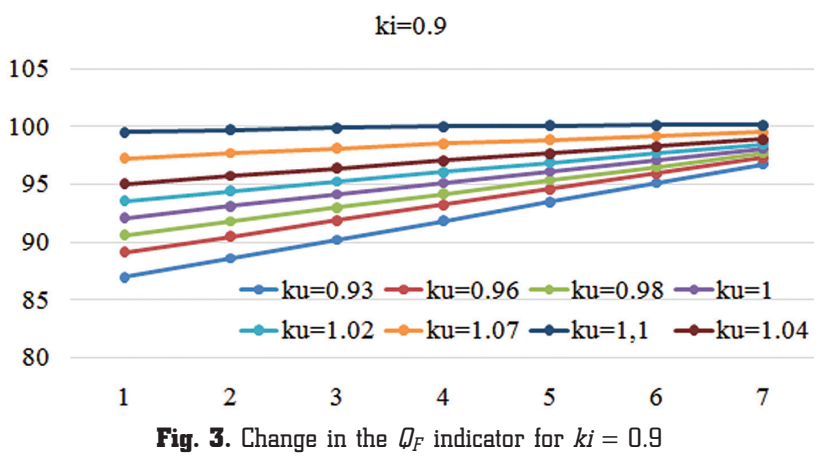

These results illustrate the need to establish clear management laws when implementing DSM programs for power consumption facilities, including warehouses.

\section{SWOT analysis of research results}

Strengths. Analysis of the peculiarities of the formation of an energy efficient transport and logistics infrastructure made it possible to single out the process of increasing the level of energy efficiency of warehouses as one of the main tasks of modernizing the transport and logistics industry. According to the results of the research, it is established that warehouses, which are one of the most important components of logistics systems, are complex subsystems whose functioning determines the efficiency, in particular of energy, of the logistics chains as a whole.

It is worth highlighting the following strengths:

- increase in consumption in the transport and logistics sector;

- introduction of economic measures aimed at stimu-

lating the reduction of electricity consumption;

- reduction of technological costs;

- use of modern systems to monitor electricity consumption;

- reduction of peak loads in the United Energy System (UES) of Ukraine;

- advantageous geographical position.

Weaknesses. World practice indicates the success of demand management projects and their positive impact on the general consumption schedule, which is especially important in modern conditions of Ukraine. However, the weaknesses are:

- insignificant number of regulating capacities;

- weak legislative base and system of state support;

- lack of competition between generating companies; - uncompensated power supply system of UES of Ukraine for reactive power and providing the required voltage level;

- low level of metering devices for electricity consumers;

- low culture of electric energy consumption;

- lack of sufficient economic incentives for the consumer to manage the demand for electricity;

- significant deterioration of network equipment;

- reduction in the capacity of power lines.

Opportunities. Solving the issue of increasing energy efficiency against the backdrop of a balancing energy market in a liberalized market requires solving not only the issues of control of technological processes, but also organizational and methodological ones. The enterprises of the transport and logistics industry are interested in the rhythmic loading of their own capacities in accordance with the stages and intervals of storage, the analysis of the costs of associated resources, and depend on the cost of electric power. Also these possibilities are:

- modernization of existing facilities and development of new ones;

- attracting consumers to power regulation in the power system;

- possibility to reduce specific fuel consumption and electricity supply;

- development of renewable energy sources;

- establishment of a system for assessment of the methods for managing power consumption.

Threats. Threats include the following:

- lack of favorable conditions for attracting investments;

- increase in inflation in Ukraine;

- low solvency of electricity consumers;

- irrational regional policy;

- population migration;

- low level of interest in the introduction of methods for managing electricity consumption.

\section{Conclusions}

1. Analysis of energy efficiency factors has shown the importance of paying attention to improving the energy efficiency of warehouses as one of the weighty reserves of reducing costs in the logistics chain. The criteria of conformity to the European classifications of warehouses are formed. It is shown that the formation of an energy efficient transport and logistics infrastructure will allow:

- to introduce energy-saving technologies through

supply chain management based on the concept of «green logistics» and the use of railway transport;

- to solve the problem of interaction of various modes of transport and to improve the quality of integrated cargo traffic servicing;

- to reduce the transportation cost of goods by reducing energy consumption;

- to reduce pollution of the environment as a result of a decrease in the volume of transport work per unit of cargo.

2. An assessment of the unevenness of power consumption graphs of warehouses as a specific type of load is made by modifying the $Q_{F}$ index. The obtained characteristics for the modified $Q_{F}$ index indicate the possibility of optimizing consumption, when controlling the power consumption mode.

3. The feasibility of implementation of DSM programs for warehouses is shown. A methodology for assessing the nature of electricity consumption and its quality is suggested, which makes it possible to identify factors related to the consumer and require a solution by analyzing the mode of electric energy consumption.

\section{References}

1. Davtyan, Y. V. The Theoretical Foundations of the International Transport Corridors and their Role in the Economy of Ukraine [Text] / Y. V. Davtyan // Business Inform. - 2012. № 12. - P. 151-155. 
2. Cherniavskyi, Yu. I. Ekolohichni aspekty rozvytku mizhnarodnoho transportnoho korydoru Yevropa-Aziia [Text] / Yu. I. Cherniavskyi // Ekonomika pryrodokorystuvannia i okhorony dovkillia. 2013. - P. 227-234.

3. Stechenko, D. M. Rozmishchennia produktyvnykh syl i rehionalistyka [Text]: Handbook / D. M. Stechenko. - Kyiv, 2006. - 396 p.

4. Kopylova, O. A. Metodika formirovaniia energoeffektivnoi transportno-logisticheskoi infrastruktury [Text] / O. A. Kopylova, A. N. Rahmangulov // Sovremennye problemy transportnogo kompleksa Rossii. - 2012. - № 2. - P. 45-53.

5. Rakhmanhulov, A. N. Vybir mists dlia lohistychnykh potuzhnostei [Text] / A. N. Rakhmanhulov, O. A. Kopylova, Ye. K. Autiv // Svit transportu. - 2012. - № 2. - P. 19-22.

6. Razvitie logisticheskih tsentrov [Electronic resource] // Central Asia Regional Economic Cooperation (CAREC). - 2013. Available at: \www/URL: http://www.carecprogram.org/uploads/events/2013/CFCFA-training-KGZ/009_103_209_logistics-center-development-ru.pdf

7. Klassifikatsiia skladskih pomeshchenii [Electronic resource] // Commercial Property. - Available at: \www/URL: http:// commercialproperty.ua/references/warehouse.php

8. Profesiini rishennia dlia skladskoi lohistyky [Electronic resource] // «IMVO»COMPANY. - Available at: \www/URL: http://www.imvo.lviv.ua/uploads/files/IMVO_presentation_ ukr.pdf. - 12.12.2016.

9. Evteev, S. Aiti - logistika i sklad: kompleksnye resheniia dlia avtomatizatsii logistiki [Electronic resource] / S. Evteev // IT. Available at: \www/URL: http://www.it.ru/itrfid/effect.pdf

10. Knight Frank [Electronic resource]. - Available at: \www/ URL: http://www.knightfrank.ru/

11. Directive 2012/27/EU of the European Parliament and of the Council of 25 October 2012 [Electronic resource] // Official Journal of the European Union. - 2012. - L 315/1. - Available at: \www/URL: http://eur-lex.europa.eu/LexUriServ/LexUriServ.do?uri=OJ:L:2012:315:0001:0056:en:PDF

12. Sostoianie, tranzitnyi potentsial, problemy i perspektivy razvitiia Sistemy mezhdunarodnyh transportnyh koridorov (MTK) Rossii na primere dostavki i tamozhennogo oformleniia mezhdunarodnyh ekspress-gruzov [Electronic resource]. - Riga, June 2014. - Available at: \www/URL: http://www.rmsforum.lv/ admuploads/file/3_shljapnikov_transbaltica_2014.pdf

13. Karpenko, O. A. Doslidzhennia perevah lohistychnoho pidkhodu pry orhanizatsii system materialno-tekhnichnoho zabezpechennia pidpryiemstv [Text] / O. A. Karpenko, S. O. Kovalchuk, Ye. O. Yefimova // Upravlinnia proektamy, systemnyi analiz i lohistyka. Tekhnichna seriia. - 2012. - Vol. 9. - P. 82-85.

14. Nikolaichuk, V. Vzaimosviaz' i razlichiia logistiki i marketinga [Electronic resource] / V. Nikolaichuk // Economy of Ukraine. - 1999. - № 4. - Available at: \www/URL: http://masters. donntu.org/2003/fem/gavrischuk/library/index1.htm

15. Krykavskyi, Ye. Ekonomichnyi potentsial lohistychyykh system [Text] / Ye. Krykavskyi. - Lviv: DU «Lvivska politekhnika», 1997. - 168 p.

16. Oklander, M. A. Kontury ekonomichnoi lohistyky [Text]: Monograph / M. A. Oklander. - Kyiv: Naukova dumka, 2000. - 174 p.

17. Sergeev, V. I. Logistika v biznese [Text]: Handbook / V. I. Sergeev. - Moscow: INFRA-M, 2001. - 608 p.

18. Harrison, A. Logistics Management and Strategy [Text]/ A. Harrison, R. Van Hoek. - Ed. 2. - Financial Times/Prentice Hall, 2004. - $336 \mathrm{p}$

19. Classification warehouse [Electronic resource] // Bachfest Leipzig. - April 11, 2014. - Available at: \www/URL: http:// bachfest-leipzig.com/classification-warehouse/
20. SwissReal Group [Electronic resource]. - Available at: \www/ URL: http://swissreal.com/

21. Goswami, D. Y. Energy Efficiency and Renewable Energy [Text]: Handbook / D. Y. Goswami, F. Kreith. - Ed. 2. - CRC Press, 2015. - 1846 p.

22. Energy Efficiency Indicators: Fundamentals on Statistics [Text]. Paris: OECD/IEA, 2014. - 388 p

23. Ożadowicz, A. Energy saving in the street lighting control system - a new approach based on the EN-15232 standard [Text] / A. Ożadowicz, J. Grela // Energy Efficiency. - 2016. P. 1-14. doi:10.1007/s12053-016-9476-1

24. Hernández-Santoyo, J. Trigeneration: an alternative for energy savings [Text] / J. Hernández-Santoyo, A. Sánchez-Cifuentes // Applied Energy. - 2003. - Vol. 76, № 1-3. - P. 219-227. doi:10.1016/s0306-2619(03)00061-8

25. Ghicajanu, M. Programs of Energy Efficiency - Demand Side Management (DSM) [Electronic resource] / M. Ghicajanu // International conference on economics, law and management. 2008. - Available at: \www/URL: http://www.upm.ro/proiecte/ EEE/Conferences/papers/S335.pdf

26. Opryshko, V. Osoblyvosti intehratsii osnovnykh prohram i metodiv z keruvannia popytom spozhyvannia elektroenerhii [Text] / V. Opryshko // III Mizhnarodna naukovo-tekhnichna ta navchalno-metodychna konferentsiia «Enerhetychnyi menedzhment: stan ta perspektyvy rozvytku - PEMS16». 2016. - P. 88-89.

27. Stognii, B. S. The evolution of intelligent electrical networks and their prospects in Ukraine [Text] / B. S. Stognii, O. V. Kyrylenko, O. V. Prahovnyk, S. P. Denysiuk // Tekhnichna Elektrodynamika. - 2012. - № 5. - P. 52-67.

28. Drehsler, R. Izmerenie i otsenka kachestva elektroenergii pri nesimmetrichnoi i nelineinoi nagruzke [Text] / R. Drehsler; Translation from Czech: A. A. Okin. - Moscow: Energoatomizdat, 1985. - 113 p.

\section{ЛОВЫШЕНИЕ УРОВНЯ ЭНЕРГОЗФФЕКТИВНОСТИ СКЛАДСКИХ ПОМЕЩЕНИЙ С ИСПОЛЬЗОВАНИЕМ МЕХАНИЗМОВ УПРАВЛЕНИЯ CIPOCA}

Исследована проблема повышения уровня энергоэффективности складских помещений в цепи транспортно-логистической системы. Установлена целесообразность применения программ по управлению спросом на энергетические ресурсы с последующим анализом параметров и качества электроэнергии как одного из ключевых факторов повышения энергоэффективности. Представлены результаты применения показателя неактивной мощности Фризе при оценке неравномерности потребления электрической энергии.

Ключевые слова: управление спросом на энергетические ресурсы, энергоэффективность сооружений, транспортно-логистическая инфраструктура.

Denysiuk Sergii, Doctor of Technical Sciences, Professor, Department of Power Supply, National Technical University of Ukraine «Igor Sikorsky Kyiv Polytechnic Institute»,Ukraine,e-mail: spdens@ukr.net, ORCID: http://orcid.org/0000-0002-6299-3680

Kotsar Oleg, PhD, Associate Professor, Department of Power Supply, National Technical University of Ukraine «Igor Sikorsky Kyiz Polytechnic Institute»,Ukraine, e-mail: kovpers@ukr.net, ORCID: http://orcid.org/0000-0002-7958-2335

Opryshko Vitalii, Postgraduate Student, Department of Power Supply, National Technical University of Ukraine «Igor Sikorsky Kyiv Polytechnic Institute», Ukraine, e-mail: livestrongtm@gmail.com, ORCID: http://orcid.org/0000-0003-4963-2490 